$\operatorname{Ag} 8: 3465$

Bulletin 465

\title{
Cytological and Genetic Studies of Sterility in Inbred and Hybrid Maize
}

\author{
Frances .J. Clatik
}

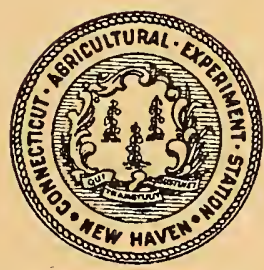

Canmertirut

Agxiultural Fixperiment Station

New Thanen 


\section{CONTENTS}

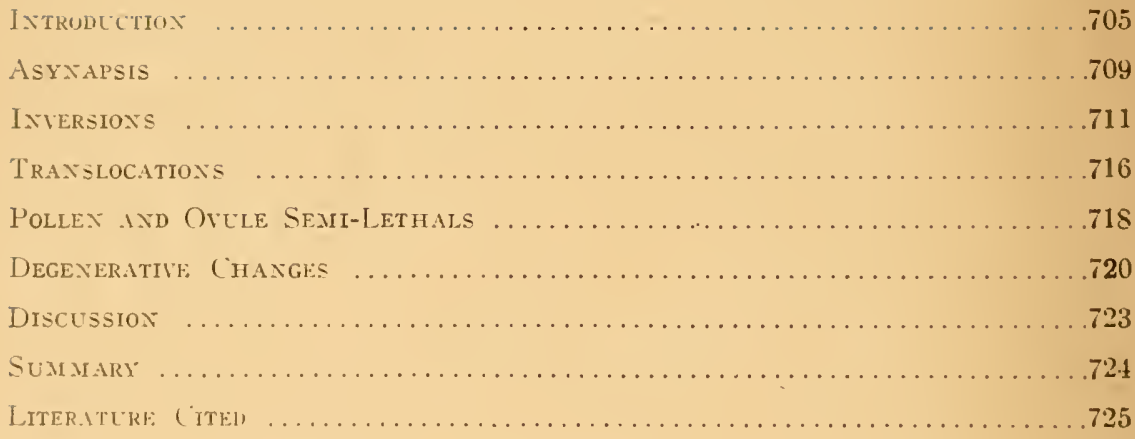




\title{
Cytological and Genetic Studies of Sterility in Inbred and Hybrid Maize'
}

\author{
Frances J. Clatis
}

A

DISCUSSION of sterility in maize has applications to both practical and theoretical problems. One aspect is related to the increased growing of hybrid corn in recent year's entailing more extensive breeding programs for the production of inbreds and hybrids. It is of practical value to determine and eliminate causes of sterility in inbred lines in order that uniform production may be assured in hybrid corn.

Partial or complete sterility may be manifested in corn by poorly filled ears, aborted pollen, and defective seeds, or a combination of these effects (Figures 1 and 2). Hereditary and non-hereditary failure of seed formation have been described by Mangelsdorf (22). Certain environmental conditions, such as relative growth rates of tassels

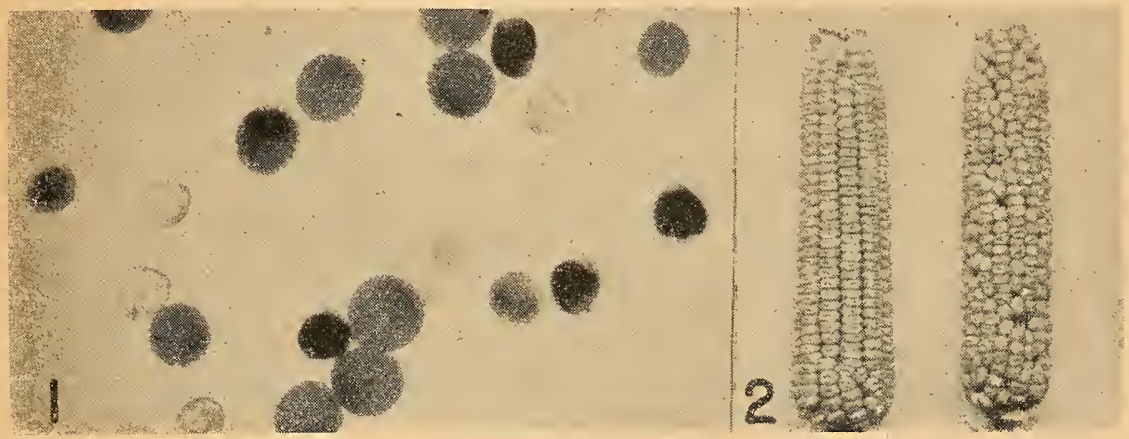

FIGURES 1 AND 2.

Figure 1. Photomicrograph of pollen, stained with a weak solution of iodine, showing two types of aborted pollen grains. Smaller grains are darker in the photograph, and empty grains have no included starch. The large grains are normal.

FIGURE 2. Semi-sterile ear (right) and normal ear of maize. The semi-sterile ear has about 50 percent aborted ovules.

and ears, insect injury, diseases and growing conditions, may also change the development of ears and tassels. Usually such factors may be separated from sterility caused by aberrant chromosome behavior or genetic factors for lethal effects on gametes. However, if the silks receive insufficient pollen, the resulting ear often cannot be distinguished from a partially sterile one. Sterility which is inherent in the genetic or chromosomal constitution of the plant will be transmitted to succeeding generations through the pollen or egg cells dation.

I This investigation was supported in part by a grant from the Rockefeller Foun- 
or thromgh botls. and usually rewults in relatively consistent percentages of abuted ovules or pollen in the progeny.

The results of inbreeding and of ronsing inhred lines have been

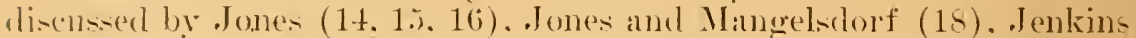

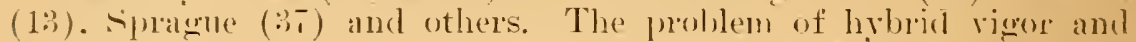
aspects of heterosis have been reviewed by East (10). vingheton (3j)

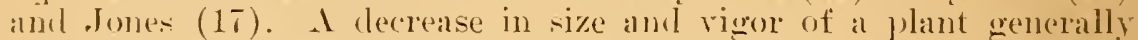
arcompanies inbreerling and the approach to homozyosity. Certain lines of maize become difficult to mantain becanse of smoh weakening. and are particularly susceptible to unfarorable growing anditions. Hybrids form such inbreds may, howerel, be puite vigorous. This farct has been wiven theoretical consideration by Jones (1T). Causes of poorly filled ears of corn and partionlarly weak plants have been detrpmined for some stocks by detailed arenctic and chromonomal analrses. but such methods have not been generally applied in corn hreecling programs.

Problems of theoretical interest are also associated with a leytological study of sterility in maize. Singleton (3.) and l)obzhansky and Rhoales (9) have suggested rytological and genetic technipuen for determining and locating factors responsible for heterosis. Burnham and Cartledge (T) have ontlined a method for locating factor involred in resistance to disease. Theoretical simificance can also be given to the variations fomm among a large number of plants. as in a breceling program. Types of plants that are aber'ant in leaf growth. chlorophyll patterns, plant form and fertility of gametes ale often observed. The fremencr of ocempence of slich chandes constitutes a special problem to be attacked only in experiments clesigned for the purpose. Howerere, when larege mombers of plants are gromen it is pos-

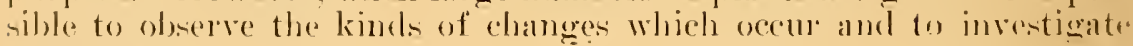
the (alli-es.s.

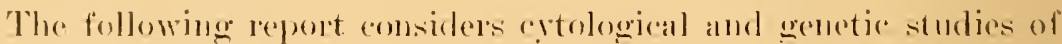

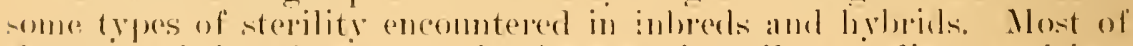

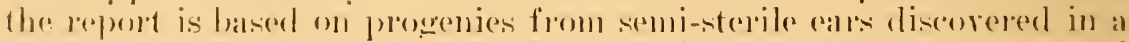

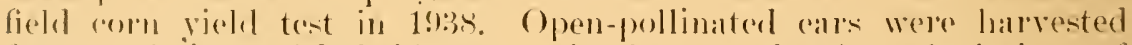

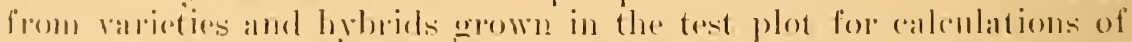

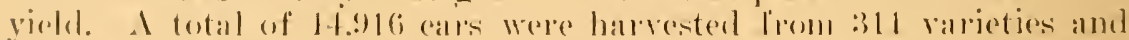

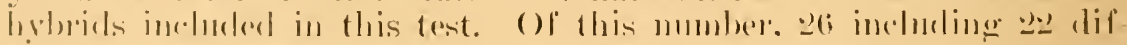

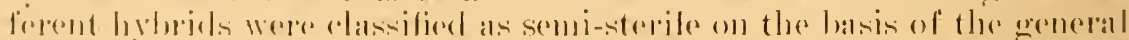
al)

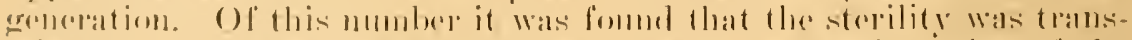

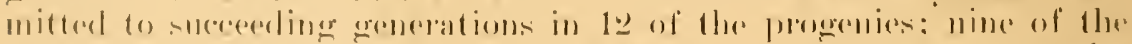

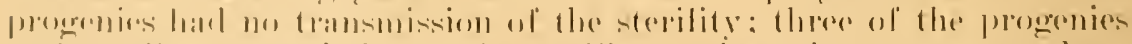

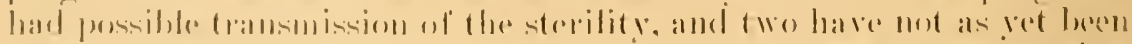

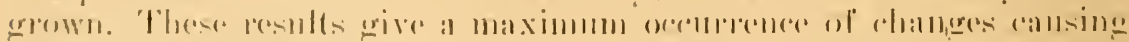

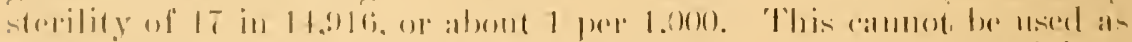

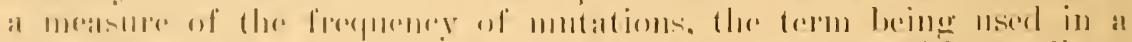

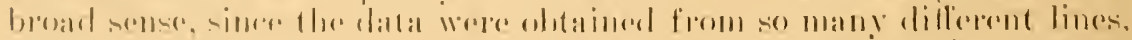

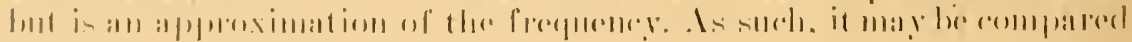


in a general way only with values found in experiments designed to determine the frequency of naturally ocomring mutational changes. The cytological and genetic analyses of the progenies from the semisterile ears were made in order to determine the kinds of maturally occurring changes which may be detected more particularly with cytological methods.

Inother series of semi-sterile ears used in this investigation was obtained from rarious hybrids grown in other test plots. Six of these wero from hybrids with the inbred Connecticut 243 ; five were fron other field corn hybrids, and one was from a sweet corn hybrid. 'The sterility was found to be transmitted to six of the progenies grown. Five of the progenies showed no transmission of the sterility, and one a possible transmission of the sterility. The progeny from the semisterile ear having questionable transmission in this group of hybrid ears is difticult to classify both genetically and cytologically since this hybrid, one with Connecticnt 243, segregates a striped plant which is partially ear-sterile, does not always mature and is not inherited as a simple recessive.

The transmissible sterilities identified in the two gromps of semisterile ears were found to be due to three general causes: (a) translocation between non-homologous chromosomes, (b) inversions of regions of chromosomes and $(c)$ genetic factors for pollen or ormle semilethals in which no cytological change could be found. I summary of the results obtained in these series of semi-sterile ears is given in 'Table 1. Six different translocations have been found, one inversion and three definite pollen or orule semi-lethals. with the addition of three possible semi-lethals. The progenies in which transmission of the sterility was definitely established showed semi-sterility in approximately 50 percent of the plants, whereas in progenies with doubtful transmission of the sterility about 25 percent of the plants were classified as segregating defective gametes.

The translocations and the inversion that have been identified are different from any that have been previously reported. This indicates that the changes are of a spontaneous nature and not due to any contamination from genetic stocks grown at the same time.

Five inbred lines of dent corn have also been examined. Hybrids with one of the inbreds were found to be semi-sterile, and two of the inbreds were characterized by some pollen abortion. A cytological examination was made to determine the canses of the sterility. Two inbreds were found to have variable amounts of asynapsis; one was found to have a small inversion: one was found to be homozygous for a translocation, and one was found to be mosaic for a chromosomal change. The last inbred is also characterized by degenerative changes in ear development. but any relation between such derelopment and the cytological changes has not been established. One of the inbreds having asynapsis has also been found to segregate a plant with a striped chlorophyll pattern. but the segregation is not that of a Mendelian recessive. 


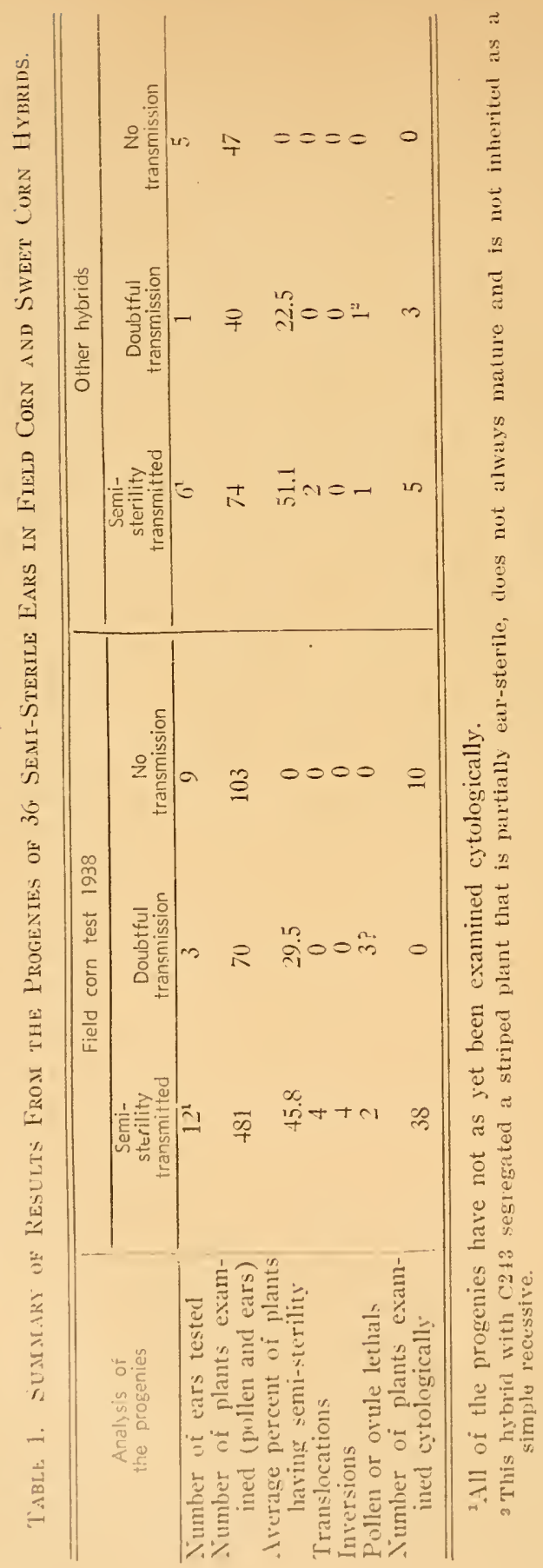


The results of the eytological and genetic study of the inloreds and hybricls will be discussed under the following divisions: asynapsis, inversions, translocations, pollen and ovule semi-lethals, and degenerative changes. Unless otherwise noted, all preparations made were aceto-carmine smears from anthers fixed in a tixing solution composed of 3 parts 95 percent ethyl alcohol and 1 part glacial acetic acid. according to the method of McClintock (24).

\section{ASYNAPSIS}

The failure of the chromsomes to maintain close synapsis in the meiotic divisions has been found in a number of plants $(3,11,12,19$. $20,28,31)$. Beadle $(1,2)$ found such a condition in maize to be inherited as a simple recessive gene $(a s)$. Variable numbers of gametes are aborted as a result of the action of this gene since one or more chromosomes fail to be included in the nuclei of part of the developing gametes. An examination of the pollen in inbred C243 revealed that about 50 percent of the pollen was of aborted grains-small or without any included starch grains. A cytological examination of meiosis indicated that the cause of this partial pollen sterility was in the lack of complete synapsis of the chromosomes. It is doubtful whether this condition is the same as that reported by Beadle, referred to above, since the asynapsis is not as complete, and the ears show very little if any sterility. Counts of microsporocytes at the diakinesis stage of meiosis are given in Tables 2 and 3.

Table 2. Counts of the Numbers of Cells Having Uinivalents at Diakinesis and Metaphase. From Two Plants of Inbred C243.

\begin{tabular}{ccccc}
\hline Plant & $\begin{array}{l}\text { Number of } \\
\text { cells with } \\
\text { 10 bivalents }\end{array}$ & $\begin{array}{l}\text { Number of } \\
\text { cells with } \\
\text { univalents }\end{array}$ & $\begin{array}{c}\text { Total } \\
\text { cells }\end{array}$ & $\begin{array}{c}\text { Percent of } \\
\text { cells with } \\
\text { asynapsis }\end{array}$ \\
\hline $\begin{array}{c}\text { 38-392-1 } \\
\text { Diakinesis }\end{array}$ & 107 & 234 & 341 & 68.6 \\
$\begin{array}{c}\text { Metaphase } \\
\text { 42G 17-3 }\end{array}$ & 25 & 138 & 163 & 84.7 \\
Diakinesis & 26 & 34 & 60 & 56.7 \\
\hline \hline
\end{tabular}

Table 3. The 406 Cells From Colum Two of Table 2 Classified According to the Number of Univalents.

\begin{tabular}{crrrrrrrr}
\hline \hline Plant & \multicolumn{7}{c}{ Number of univalents } & \multicolumn{1}{c}{ of } \\
\hline $38-392-1$ & 178 & 130 & 48 & 13 & 1 & 1 & 1 \\
$42 \mathrm{G} 17-3$ & 20 & 10 & 3 & 1 & 0 & 0 & 0 \\
\hline \hline
\end{tabular}

It is evident that most of the cells had only one or two chromosomes which did not maintain their synapsis up to the time of diakinesis and metaphase. In many cells in which complete separation of some homologues was observed there were also one or more of the bivalents associated only at the ends. The number of chromosomes with partial asynapsis had no relation to the number of univalents in the cell. When univalents are present in the meiotic divisions, they are 
often mot inclucled in eithere of the two danghter molei alue to their lagrering on the spinclle or heing left otf the spinclle figure. Small micomuclei which become pyonotic derelop from mivalents excluded from developing telophase nuclei. This is similar to the behavior of framment chromosomes (ö 6 ). Quartets that were commed with refmence to the presence of micromulei are tabulated in Table $t$.

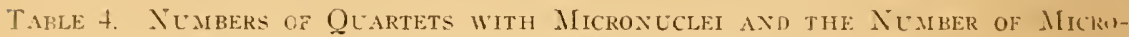
NLCLEI IX THE Microspores.

\begin{tabular}{|c|c|c|c|}
\hline Plant & $38-392-1$ & $42 G 17-1$ & $42 G \quad 17-2$ \\
\hline $\begin{array}{l}\text { Quartets with } \\
\text { micronuclei }\end{array}$ & 30 & 113 & 110 \\
\hline $\begin{array}{l}\text { Quartets with wo } \\
\text { micronuclei } \\
\text { VIicrospores with: }\end{array}$ & 20 & 25 & 10 \\
\hline 0 micronuclei & 119 & 249 & 104 \\
\hline 1 & 61 & 227 & 210 \\
\hline . & 12 & 00 & 82 \\
\hline$\overline{3}$ & 6 & 11 & 21 \\
\hline ". & 1 & 5 & 3 \\
\hline 5 & 1 & 0 & () \\
\hline $\begin{array}{l}\text { Percent of microspores } \\
\text { with micronuclei }\end{array}$ & 40.5 & 55.0 & 05.8 \\
\hline
\end{tabular}

The number of micromuclei in a quartet is indicative of the anmomnt of pollen abortion to expect. althomeh a chlomosome left out in a presvions dirision is distributed at ranclom to one of fom microspoles and may be included in a developing nuclens. Two pollen comts wero

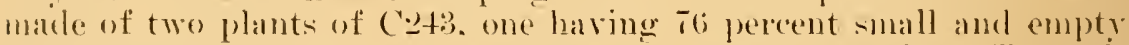

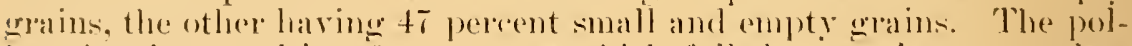
len abortion resulting from sposes whieh failed to receive a complete

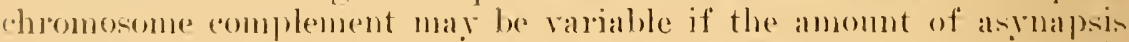
is elependent 11 pon envirommental eonelitions. Fome indication of this

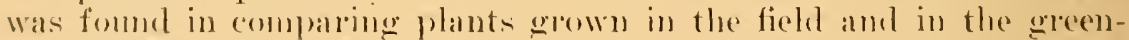

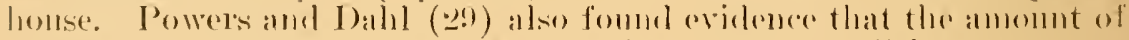
asymapsis in maire ma! depend on envirommental comelitions.

In adelition to the plants of (e)

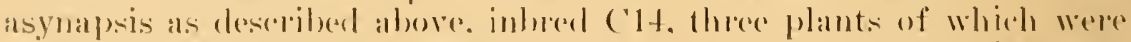

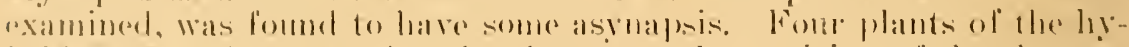

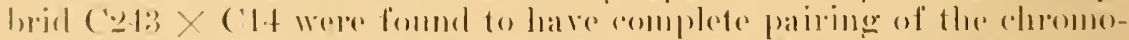

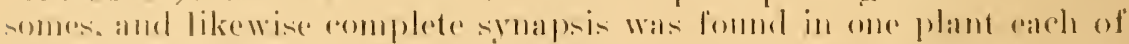

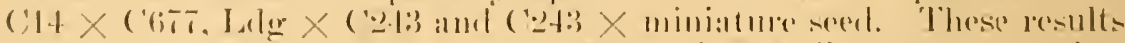

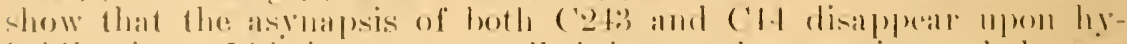

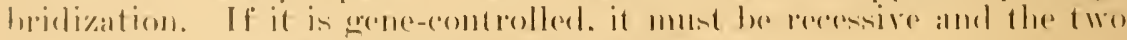

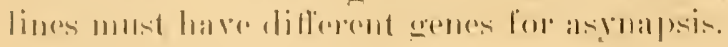

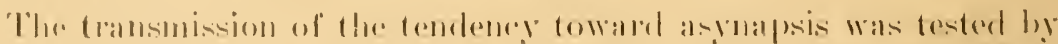

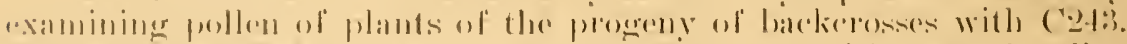

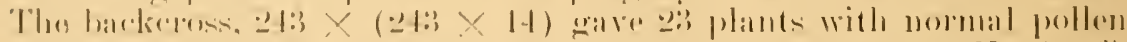

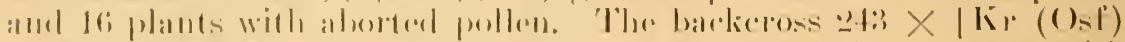

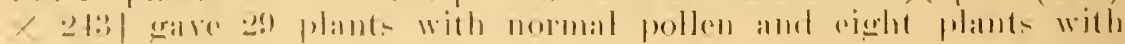


aborted pollen. A 1:1 ratio would be expected from a simple gene ratio. 'Transmission is eflected through both pollen and eggs but, since these numbers are small, it cannot be stated definitely that the inheritance is that of a simple recessive gene. Partial asynapsis seems to occur frequently in inbred plants and may well have some physiological basis for expression.

\section{INVERSIONS}

Two inversions were found during the examination of the inbreds and hybrids. One of these included the centromere, as was found by the prophase synapsis of the chromosomes and by the absence of bridges and fragments in the meiotic divisions. The other inversion does not inclucle the centromere, as was shown by the cytological examination. Types of crossovers in inversions, and gametes produced are discussed by McClintock (26), Darlington (8) and Sturtevant and Beadle (39).

The inbred Iowa La has been grown for about 14 years. Cytological examination of plants of this inbred indicated that a small inversion was present although the inbred might have been expected to be free from aberrations after the period of inbreeding. One plant was examined cytologically in the summer of 1938 to determine the morphology of the chromosomes. Bridges and small fragments were found at the meiotic divisions, and it was concluded that the plant was heterozygous for a small inversion. The progeny of this plant was grown and 10 plants of the next generation were also found to be heterozygous for an inversion since bridges and fragments were found. It was concluded that the inversion is a short one since the fragment is so small, but the location on the chromosomes was not observed. There is some evidence that it may be the small terminal inversion, not including the centromere, on the short arm of chromosome $S$ (previously reported by McClintock, 25), and the amount of crossing orer is similar to that observed for the chromosome 8 inversion. The frequency of crossing over in this inversion was determined by counts of the types of bridges and fragments observed at the meiotic divisions (Table 5 ).

Table 5. Counts of Bridges and Fragments at the First Meiotic Division in Four Plants Having a Small Heterozygous Ixversion.

\begin{tabular}{|c|c|c|c|c|c|c|c|}
\hline $\begin{array}{l}\text { Plant } \\
\text { no. }\end{array}$ & $\begin{array}{c}\text { Non-cross- } \\
\text { overs }\end{array}$ & $\begin{array}{l}\text { Bridge plus } \\
\text { fragment }\end{array}$ & $\begin{array}{l}\text { Bridge, no } \\
\text { fragment }\end{array}$ & $\begin{array}{l}\text { Fragment, } \\
\text { no bridge }\end{array}$ & $\begin{array}{c}\text { Two } \\
\text { fragments }\end{array}$ & Total & $\begin{array}{l}\text { Percent } \\
\text { cross- } \\
\text { overs }\end{array}$ \\
\hline $\begin{array}{r}\text { Anaphases } \\
836-6 \\
-7 \\
-9 \\
-11\end{array}$ & $\begin{array}{r}46 \\
34 \\
7 \\
38\end{array}$ & $\begin{array}{r}13 \\
3 \\
2 \\
8\end{array}$ & $\begin{array}{c}2^{1} \\
1^{1} \\
0 \\
1+1 ?\end{array}$ & $\begin{array}{l}4 \\
2 \\
0 \\
2\end{array}$ & $\begin{array}{c}1+1 ?^{2} \\
0 \\
0 \\
0\end{array}$ & $\begin{array}{r}67 \\
40 \\
9 \\
50\end{array}$ & $\begin{array}{l}29.9 \\
15.0 \\
22.2 \\
22.0\end{array}$ \\
\hline $\begin{array}{c}\text { Telophases } \\
-7\end{array}$ & 322 & 17 & 1 & 48 & $2^{3}$ & 390 & 17.4 \\
\hline
\end{tabular}

1 Fragment possibly attached to bridge.

3 No bridge; bridge in one?

ane with bridge; one with no bridge. 


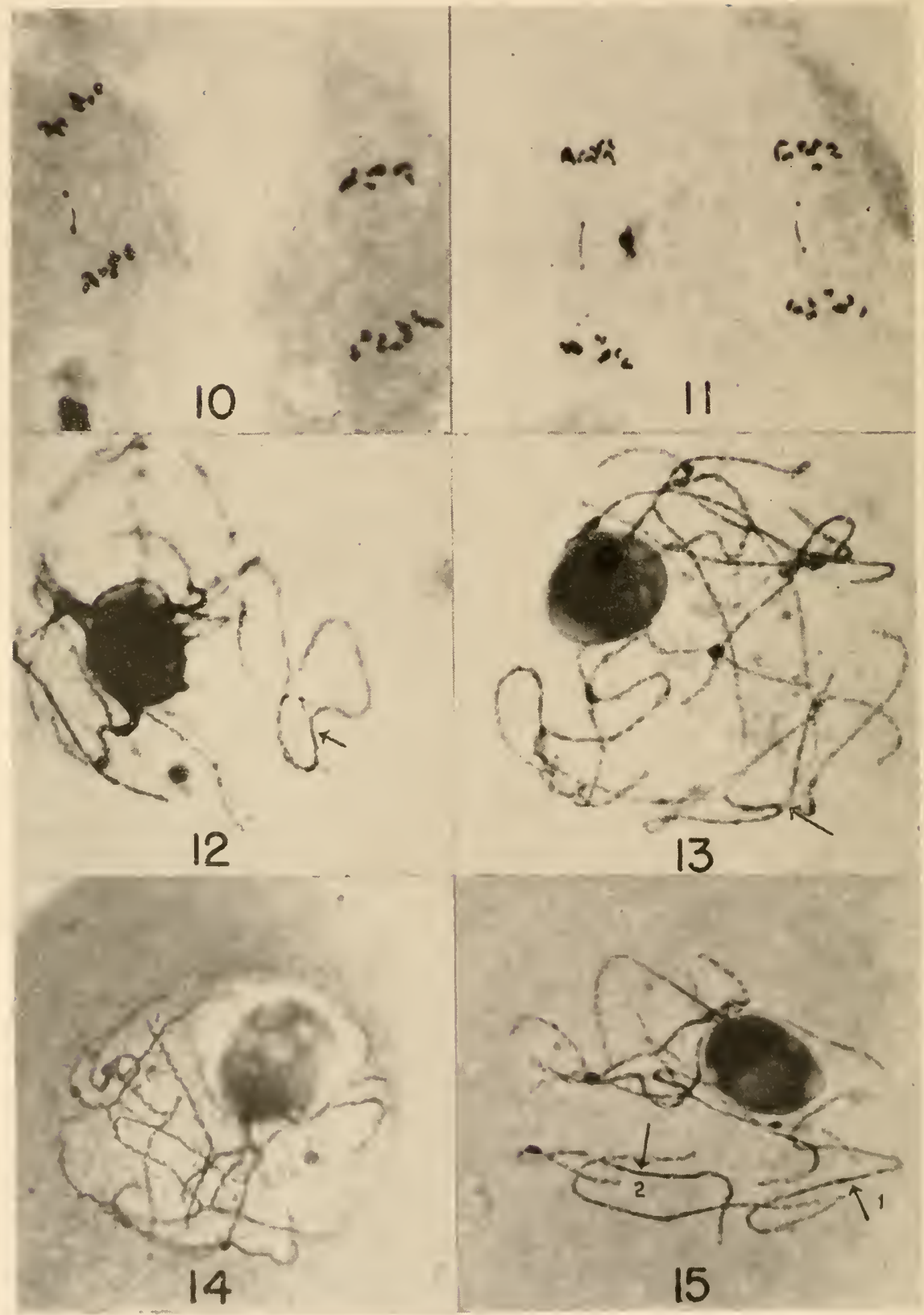

figarems 10-15.

(lixplanation on opposite page.) 
A single crossover within the inverted region is represented in these counts by a bridge and a fragment. If the fragment is included in one of the developing telophase nuclei, only a bridge is observed; if the bridge should break early, only a fragment would be observed. A clouble crossover (t-strand) is represented by a bridge and two fragments at the first meiotic division. 'The occurrence of other types of crossovers cannot be demonstrated from the division I configurations, but the presence of bridges in the second meiotic division indicates that they may occur in this small inversion (Figures 10 and 11). Six cells were found (of a total of 140 counted) having a bridge in one of the sister cells resulting from the first meiotic division. A threestrand double crossover, one crossover in the inversion and one crossover ontside the inversion, results in a bridge in one of the sister cells at the second meiotic division. A triple crossover results in a bridge in both sister cells of division II, one sporocyte of this type being observed among the 140 counted. It is evident that numerous crossovers take place within the limits of this small inversion.

The second inversion was found during the examination of the semi-sterile ears from the field corn test described above. The inversion was found in the following hybrids: $4-8 \times \mathrm{R} 4,540 \times 4-8,187-2$ $X 4-8 \mathrm{~A}$ and lowa Hybrid 13 . Since $4-8$ was one parent of the first three hybrids, it may be that this inbred carried the inversion and that it was found in the open pollinated ear of Iowa Hybrid 13 through contamination. Further examinations of the inbreds used in the making of these hybrids will have to be made before it is certain that the inbred 4-8 was heterozygous or homozygous for the inversion, or whether it occurred spontaneously in a generation prior to making the hybrids.

The limits of the inversions are shown diagramatically in Figure 3 , and photographs are shown in Figures 12 and 13 . Since the inversion includes the centromere, crossovers do not result in bridges and fragments at the meiotic divisions. However, duplicated and deficient gametes are formed as a result of crossing over, and aborted pollen grains and semi-sterile ears are characteristic. Inversions

FIgURE 10. Chromosome bridge at anaphase of the second meiotic division in one of the sister cells. See text for explanation. Plant 40-836-5 (Pedigree Iowa La.) Magnification $\times 500$.

Figure 11. Bridges at anaphase of the second meiotic division in both sister cells. See text for explanation. Plant 40-836-5. (Pedigree Iowa La). $\times 500$.

FIGURES 12 AND 13. Two sporocytes heterozygous for the inversion on chromosome 1. The loop configuration is at the lower part of each photograph. The arrows point to the centromeres. Plant 39-1428-2. (Pedigree 4-8 $\times$ R4). $\times 950$.

FIguRE 14. Heterozygous translocation between chromosomes 1 and 2 . A drawing of this translocation is given in figure 9. Plant 38-382-1. (Pedigree 237 Q2L 4A). $\times 750$.

FIGURE 15. Photomicrograph of a sporocyte from the same plant which had the sporocyte shown in figures 9 and 14. In this cell there was no translocation between chromosomes 1 and 2 . The numbers 1 and $2^{\prime}$ on the photograph are placed by the respective chromosomes. The arrows point to the centromere regions. Plant 38-382-1. (Pedigree 237 Q2L4A). $\times 750$. 


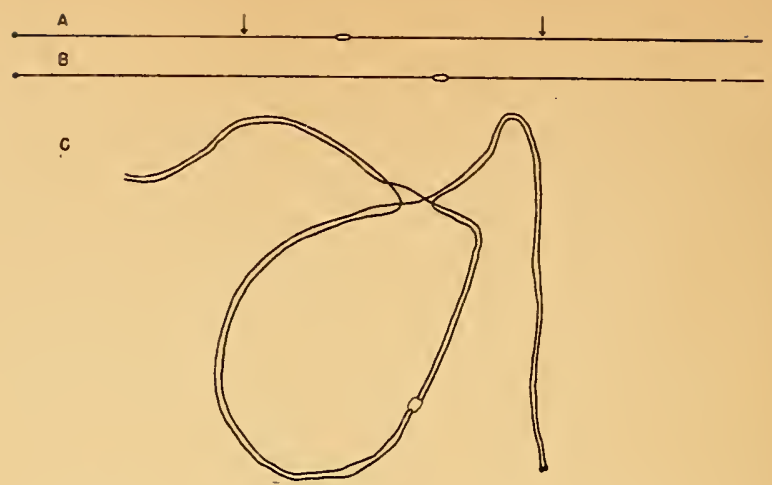

Figure 3. A. Normal chromosome 1. The arrows mark the approximate limits of the inversion.

B. Inverted chromosome 1 .

C. Outline drawing of synapsis of normal and inverted homologues at mid-prophase of meiosis. Plant 42G 8-1 (Pedigree $540 \times 4-8$ ).

The centromere region in all drawings is indicated by the lighter open circle.

including centromeres are rarely reported (Sturterant and Bearlle 39, p. 139). They may occur as frequently as other inversions, but the method of detecting them in maize by the presence of anaphase bridges and fragments does not allow the identification of those inversions including the centromere. The amount of pollen abortion in plants from two of the hybrids is given in Table 6.

Table 6. Counts of the Pollex Prodicen by Four Plants Hiviag a Hitikozygous INTERSION ON CirRomosovie 1.

\begin{tabular}{|c|c|c|c|c|c|c|}
\hline Pedigree & Plant & $\begin{array}{c}\text { Normal pollen } \\
\text { grains }\end{array}$ & $\begin{array}{l}\text { Empty } \\
\text { grains }\end{array}$ & $\begin{array}{l}\text { Small } \\
\text { grains }\end{array}$ & Total & $\begin{array}{l}\text { Percent } \\
\text { aborted }\end{array}$ \\
\hline $187-2 \times 4-8 A$ & $40-899-15$ & $\begin{array}{l}691 \\
6.47 \\
786\end{array}$ & $\begin{array}{l}209 \\
252 \\
318\end{array}$ & $\begin{array}{r}6 \\
12 \\
11\end{array}$ & $\begin{array}{r}966 \\
911 \\
1115\end{array}$ & $\begin{array}{l}28.5 \\
29.0 \\
29.5\end{array}$ \\
\hline $540 \times 4-8$ & $\begin{array}{rr}426 & 2-3 \\
+2 G & 8-1 \\
& 8-3\end{array}$ & $\begin{array}{l}539 \\
769 \\
813\end{array}$ & $\begin{array}{l}365 \\
146 \\
227\end{array}$ & $\frac{38}{-}$ & $\begin{array}{r}942 \\
914 \\
1040\end{array}$ & $\begin{array}{l}+2.8 \\
16.0 \\
22.0\end{array}$ \\
\hline
\end{tabular}

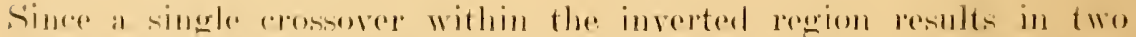

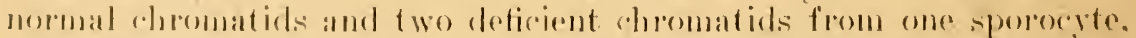

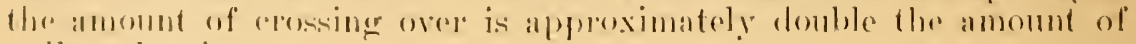
fullen almition.

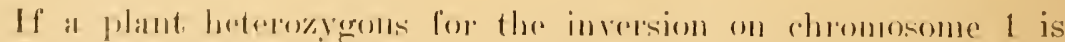

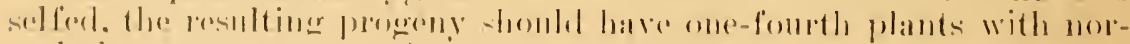

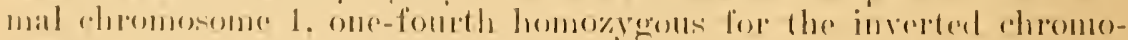

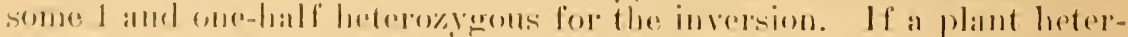

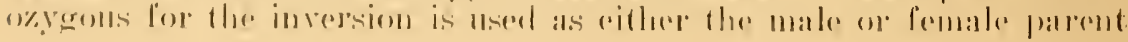


Table 7. Progeny of Plants Heterozygous for Inversion on Chromosome 1.

\begin{tabular}{|c|c|c|c|c|}
\hline Type of cross & $\begin{array}{c}\text { No. of plants } \\
\text { without inversion }\end{array}$ & $\begin{array}{l}\text { No. of semi- } \\
\text { sterile plants }\end{array}$ & Total & $\begin{array}{c}\text { Percent with } \\
\text { inversion }\end{array}$ \\
\hline $\begin{array}{l}\text { Hybrid ear open-po } \\
4-8 \times \mathrm{R} 4 \\
540 \times 4-8 \\
187-2 \times 4-8 \mathrm{~A} \\
\text { Iowa Hybrid } 13\end{array}$ & inated $\begin{array}{l}11 \\
22 \\
15 \\
22\end{array}$ & $\begin{array}{c}8^{1} \\
18^{2} \\
14^{1} \\
3\end{array}$ & $\begin{array}{l}19 \\
40 \\
29 \\
25\end{array}$ & $\begin{array}{l}42.1 \\
45.0 \\
48.3 \\
12.0\end{array}$ \\
\hline $\begin{array}{l}\text { Selfed ears from } \\
187-2 \times 4-8 \mathrm{~A}\end{array}$ & $\begin{array}{r}2 \\
10 \\
5 \\
3\end{array}$ & $\begin{array}{c}15^{1} \\
6 \\
7 \\
9\end{array}$ & $\begin{array}{l}17 \\
16 \\
12 \\
12\end{array}$ & $\begin{array}{l}88.2 \\
37.5 \\
58.3 \\
75.0\end{array}$ \\
\hline $\begin{array}{l}\text { Heterozygous inver } \\
x \text { or on normal }\end{array}$ & $\begin{array}{r}11 \\
14 \\
8\end{array}$ & $\begin{array}{r}8 \\
7 \\
11\end{array}$ & $\begin{array}{l}19 \\
21 \\
19\end{array}$ & $\begin{array}{l}42.1 \\
33.3 \\
57.9\end{array}$ \\
\hline Totals & 123 & 106 & 229 & 46.3 \\
\hline
\end{tabular}

1 One plant examined cytologically.

2 Two plants examined cytologically.

in a cross with a normal stock, one-half the resulting progeny should be heterozygous for the inversion and one-half should have normal chromosomes. When any of these three types of crosses is made, there should be one-half the progeny with normal pollen and one-half the progeny with pollen segregating aborted grains, the latter representing plants heterozygous for the inversion. Ears of most plants heterozygous for this inversion are recognizable as semi-sterile. Transmission of the inversion was tested by making the crosses described above. The data are given in Table 7 . Classitications were based on

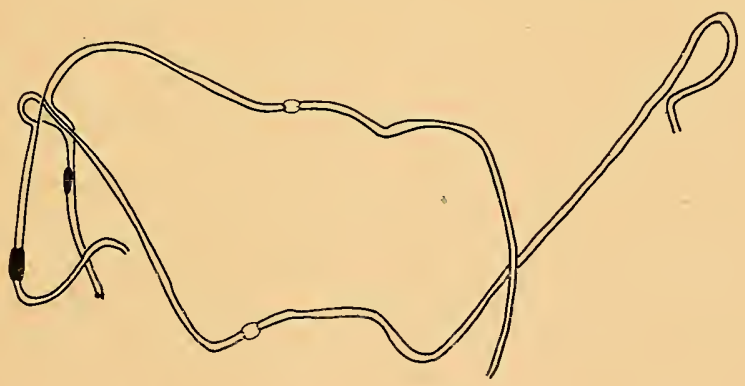

Figure 4. Outline drawing of the synapsis at midprophase of meiosis in a plant heterozygous for a translocation between chromosomes 1 and 2 . An inbred (696-3c) was found to be homozygous for the translocation. Chromosome 1 has prominent chromomeres at the end of the short arm and a heterozygous knob on the short arm. Chromosome 2 has a homozygous knob on the long arm. Plant 38-1210-8 (Pedigree 696-3c $X$ Pamunkey). 
pollen or ear examinations and in some instances were rerified by cytological examination. Crosses between the inversions from difterent sources will be made to determine if they are identical. A further proof of this would he in finding the inversion in the inbred $4-8$.

\section{TRANSLOCATIONS}

Seven different translocations have been identified during the analysis of the semi-sterile ears. One of the translocations is of particular interest since $696-3 \mathrm{c}$, a Lancaster field corn inbred, was found to be homozygous for it.

It was observed that all plants resulting from crosses with this inhred had semi-sterile ears. The hybrid 696-3c $\times$ Pamunker was examined cytologically, and the translocation was found to be present in the heterozygous condition (Figure 4). Approximately 0.4 of the short arm of chromosome 1 was exchanged with about 0.5 of the long arm of chromosome 2. The translocation had occurred in the inbred and became homozygons during inbreeding. Since no apparent growth change occurred in the inbred as a result of the translocation it was not detected until hybrids with it were grown and the translocation became heterozygous. Roberts (32), however, found evidence statistically that some homozygous translocations may affect the derelopment of the maize plant in the rate of maturing and total growth.

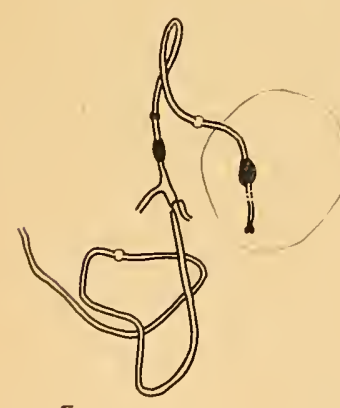

5

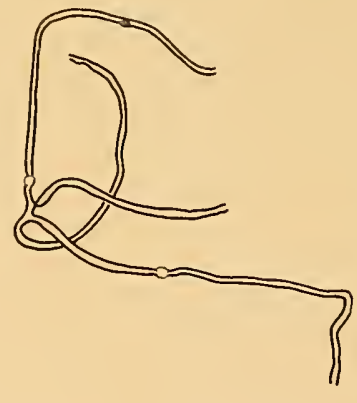

6

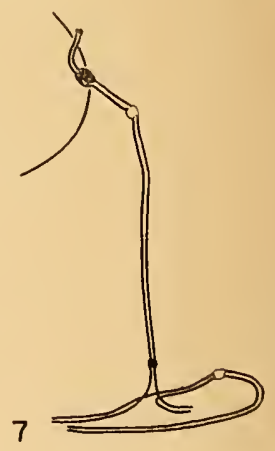

FigURES 5,6 AND 7.

()ulline drawings of synapsed chromosomes at the mid-prophase of meiosis.

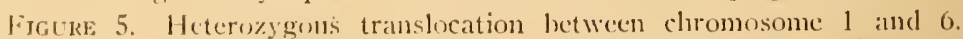
The translocition occurred near the ends of each chromosume. Chromosome 6 is attiched to the nucleolus and is characterized in this plant ly a smill anrl a large knol) on the long arm. Plant 40-894-10. (Pedigree 682-8c Х 24.3$)$.

VISGURE 6. Iletero\%gons translocation between chromosomes 2 and 5 . The translocation ocenred about micl-way on the long arm of chromosome 2 and very near the centromere on chromosome 5 . (Chromosone 5 in this plant was heterozyguts for a small knoh on the long arm. Plant 39-732-4.

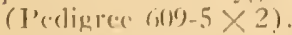

liguke 7. Heterozgons translocation hetween chromosomes 6 and 9. The translecation accurred on chromosome 6 beyond the small knob and on chromosome () near the (nel of the short arms. Plant 39-724-(1. (Peedigree $474-7 \times 474-5)$. 


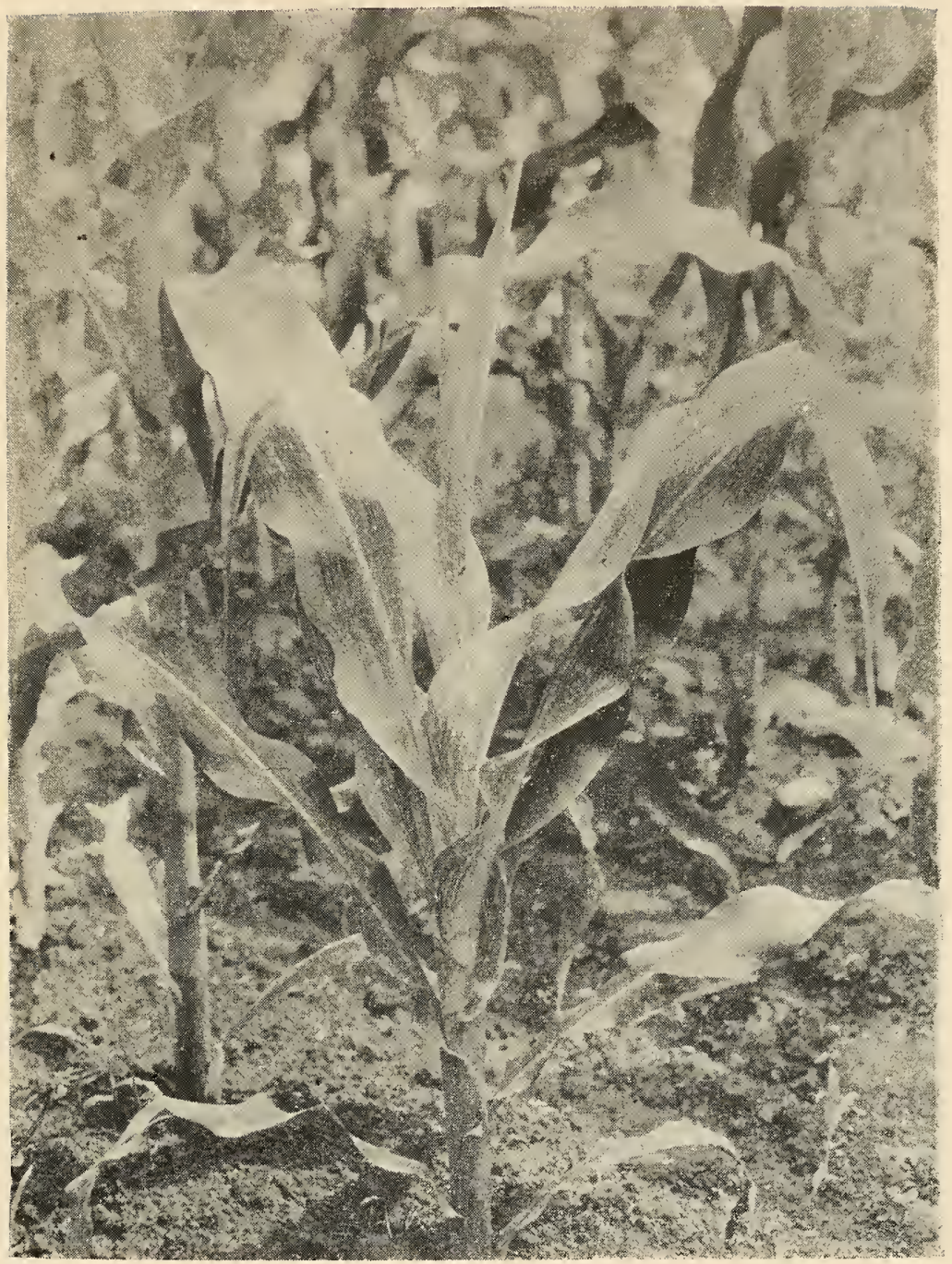

FIGURE 8. Photograph of "streaked dwarf" type of plant. The upper leaves show the typical streaking and the lower leaves are normal. This plant had not yet lost the upright habit of growth. Plant 38-15-8. (Pedigree $243 \times 14$ ). 
In a breeding program small changes would probably not influence the selection within inbred lines.

The six other translocations were found in the progenies of the semi-sterile ears. I sweet corn hybrid was found to have a translocation between chromosomes 6 and 9 . Translocations found among the field corn hrbrids were between chromosomes 1 and 6,1 and $\%$. 2 and 5.4 and $(i$. and $(j$ and $S$ (Figures 5,6 and 7 ). The presence of chromosone 6 in four out of six of the translocations occuleing spontaneously may sugoest that the naturally occuring breakage and reattachment of chlomosomes is not random. Each of the 10 chromosomes would be expected to oceur 1.2 times in six translocations takin. place at random between the chromosomes. The presence of chromosome 6 in four of the translocations is significant $(\mathrm{P}<.02)$. but the number of translocations should be increased before any general conclusion may be drawn.

The disjunction of the chromosomes having translocated regions usually results in approximately 50 percent of the gametes containing duplications and deficiencies, although some low-sterile translocations have been reported (4). The disjunction of translocated chromosomes in wheat may not be ranklom according to the report of Thompson and Hutcheson (40). 'Their calculations of the effect of crosing orer on sterility, however, do not take into account that crossing over occurs in a four-strand stage. I representative comt of the pollen produced by plants heterozygous for the translocation between chromosomes 6 and 4 is given in Table $S$.

Tajle 8. Types of Pollex Produced dy a Plant Fron Iowealth Hydrid 129. HeterozYGOLS FOR A TrANSLUCiTIOA.

\begin{tabular}{cccccc}
\hline \hline Plant & Normal pollen & Small grains & Empty & Total & $\begin{array}{r}\text { Percent } \\
\text { aborted }\end{array}$ \\
\hline 42G $11-1$ & 476 & 248 & 231 & 955 & 50 \\
$11-2$ & 664 & 235 & 188 & 1087 & 39 \\
$12-1$ & 470 & 154 & 176 & 500 & 41 \\
\hline \hline
\end{tabular}

One of the ears harrested in the fieht corn test and chassified superticially as semi-sterile appeareci to be a mosaic. Half the ear was well filled with kernels while the other half was only partially filled. Seed fom both halres of the ear was planted, and althomel 11 plants wero examined cytologically (at diakinesis) and pollen was examined from 20 plants, thror was no revence of any semi-sterility. Fars from these plants were nommal. It was conchuded that the apparent

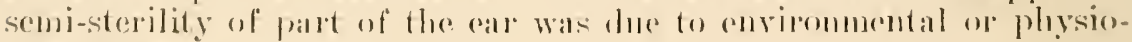
Jorical ("allisics.

\section{POLLEN AND OVULE SEMI-LETHALS}

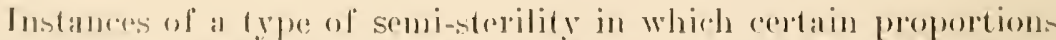

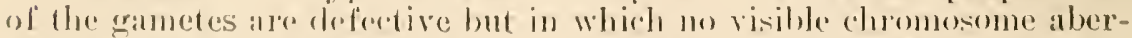
lations can be letertal have leen reported in matize, (23, 30, 33, 34,

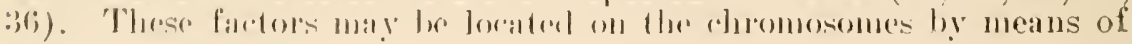


linkage with known genes, and may themselves be used as genetic characters nseful in locating other genes. Three types of semi-lethals similar to those reported by others and not associated with detectable chromosome aberations were found in the inbred and hybrid cars examined.

One of the pollen-segregating types was from the varicty Kato. In the first generation from the open-pollinated ear there were 13 plants with normal pollen and one plant that was segregating empty pollen. In sncceeding generations there were obtained 11 plants with segregating pollen (eight of these coming from a cross with the pollen parent having the segregating type) and 11 plants with normal pollen. Three of the serregating plants were examined cytologically, and it was found that the chromosomes were all apparently normal with no evidence of any deficiency, inversion or translocation. Any classification for the semi-sterility is based on pollen examinations since plants segregating empty pollen have normally filled ears. The pollen is about 30 percent aborted. Since it was found that the factor causing aborted pollen is transmitted through the pollen, it is suspected that a chromosomal aberration is present that may be small and was not detected in the cytological examinations.

From the hybrid TT209-13K X Multiple Leaming 1936, a smallpollen type was isolated. In this instance plants that are segregating the small pollen (smaller in size than normal pollen grains but well filled with starch) also have some orule abortion and produce ears appearing semi-sterile. From the open-pollinated ear of the hybrid, there were 11 plants with normal pollen and eight with segregating pollen. There were 16 plants with normal pollen and five with segregating pollen in the next generation from a selfed ear. A cross by su gave 18 plants with normal pollen and two with segregating pollen. As shown in Table 9 . there is no alteration of the expected $1: 1$ ratio

Table 9. Crosses of su $\times$ Two Plants Segregatixg Simal Pollen and su.

\begin{tabular}{cccc}
\hline \hline Plant & Su kernels & su kernels & Total \\
\hline $41-559-3$ & 202 & 177 & 379 \\
-28 & 95 & 92 & 187 \\
Total & 297 & 269 & 560 \\
Expected & 288 & 288 & \\
\hline \hline
\end{tabular}

indicating no linkage of the factor for small pollen and su. 'This factor for small pollen is different then from that reported by Singleton and Mangelsdorf, referred to above. as $s p_{1}$ reported by them is closely linked with su.

There was no evidence of any chromosomal deficiency. inversion or translocation from a cytological examination of a plant segregating the small pollen.

Another type of semi-sterility. similar to the lethal ovule (10) factor reported by Singleton (33) and Singleton and Mangelsdorf 
(36) was found in the hybrid 6r7 $\times 112-1$. These inbred parents are the same as those from which Bmmlim isolated the pa gene $(5,6)$. The semi-sterility found here was characterized by ear's which are semi-sterile in appearance due to the abortion of about 50 percent of the orules. but the pollen produced by these plants is nommal. It was determined that this is not the same 7.0 previously reported by making closses with su. 'There was no disturbance of the Su: su ratio indicating no linkage with su on ehromosome 4 . The numbers obtained were $227 S_{u}$ and 76 su (25.1 percent).

In addition to the three types of pollen and orule lethals just discussed, there were also three types which have not been grown beyond the first generation from the open-pollinated ears. For this reason they were classified in Table 1 as having questionable transmission of the sterility factors. From the hybrid La (Idt) $\times \mathrm{K}_{\mathrm{r}}$ (Osf) there were obtained 12 plants with normal pollen and two plants having some anthers with normal pollen and others with empty pollen. Trenty-two normal plants and four plants segregating empty and small grains were obtained from the hybrid 24t. From another hybrid. Iorealth Hybrid AQ, 18 normal plants rere obtained and nine plants with small or empty pollen grains. Some of the latter plantwere very small with narrow leaves, and these may have represented deficiencies of some sort since no mature seed was obtained from them.

\section{DEGENERATIVE CHANGES}

In addition to a reduction in size and rigor of maize plants duringr inbreeding, abnormalities such as small seeds, ehlorophyll defic. iencies, dwarfed plants. sterile tassels and silkless ears nua be found. some of the variations indicate that mutational changes have occurred since the inheritance is that of simple recessive or dominant genes. Then such types of plants oceur during inbreeding: they may ol may not be eliminated depending upon whether plants carrying the factors in the heteroygous condition are solected for contining the lines. Other abmormalitios oceur sporadieally, do not behave in inherilance as Mendelian recessives or dominants and may result ultimately in the loss of a particular infered line.

An example of the latter type of change appeared in line 1-i-1-:2.

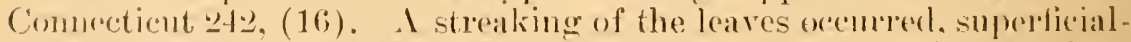
ly resombling a diseased condition, and the line was ultimately lost. inother type of streaking of the leares has appealed in the inhrod

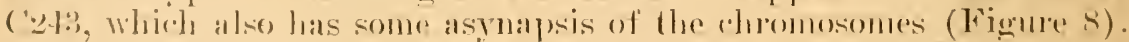

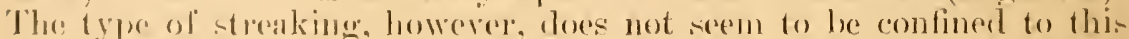

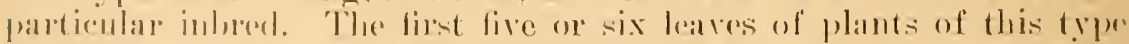

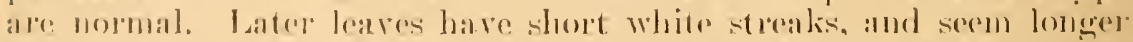

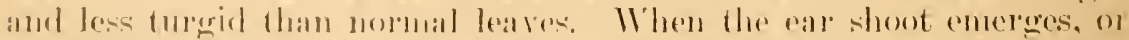

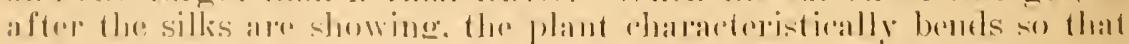

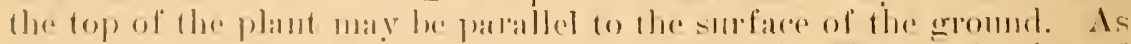

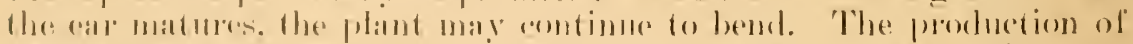
ally matme - 
stripping and bending are manifent. 'The plants are shonter than their normal sibs.

A preliminary histological examination showed that cell divisions were normal in young leat sheaths and there was no evidence of any small ring chromosome whose loss might account for the variegation (27). It was observed that cells surrounding the vascular bundles in the leaf may become abnormal in appearance and partially filled with an opaque substance. The subsequent death of these cells could account for the streaking and lack of stiffness of the leaves since in later stages some of the streaking resembles a necrosis.

Five plants which were the characteristic "streaked dwarf" type have been examined cytologically. Three of these were from hybrids with 243 , two of which had 243 as the pollen parent ( $\mathrm{Ldg} \times 243$ and $782-54 \times 243)$ and one with 243 as seed parent $(243 \times 14)$. The other two were in the inbred C237 and a related hybrid, 615-11D $X$ 615-9. Pollen from these plants and three additional streaked plants was essentially normal with no segregation type of pollen grain being present. The chromosomes were all apparently normal at the midprophase of meiosis, and there was no evidence of any deficiency, inversion or translocation. In addition two normal sib plants were examined cytologically. They were also found to have normally synapsed chromosomes and no chromosome aberration in the heterozygous condition. Pollen from these plants was normal with the exception of a few smaller pollen grains.

The "streaked dwarf" type of plant does not occur in a ratio expected on the basis of a simple recessive gene as shown in Table 10. Seven streaked plants were selfed. In the progeny of these there were 59 normal plants, and none was streaked.

Table 10. Numbers of Streaked and Normal Plants Resulting from Crosses with the "Streaked DWakF" Type of Plant.

\begin{tabular}{lccccc}
\hline \hline \multicolumn{1}{c}{ Plant } & Normal & $\mathrm{F}_{3}$ & Streaked & Normal & Backcross \\
\hline $40-127$ & 4 & 0 & - & - \\
174 & 10 & 0 & - & - \\
$814-12$ & 8 & 1 & - & - \\
$815-9$ & 38 & 1 & 14 & 3 \\
$814-6 \times 2$ & -6 & -2 & 14 & 3 \\
Total & 60 & 15.5 & 8.5 & 8.5 \\
\hline
\end{tabular}

Another type of degenerative change was found in the line 1- $\tau$, C237, (16). At the seventeenth generation of inbreeding two sib lines were separated in this inbred. Ears of one line are more poorly filled than those of the sib line, resulting in a significantly lower yield of grain. Plants with the poor ears are taller than the sib line. Two plants of this poor-ear line were examined cytologically. One of these had sporocytes in which no chromosomal changes could be observed. and the synapsis of homologous chromosomes was normal. The other 
plant was examined more completely and there were fomm a few tigmes of hetrozyons translocations. ( )n cight preparations firm different anthers. a total of 64: chromosomes conld he identified in 137 sporocytes. Of these, five sporocytes had a heterozrous translocation letween chromosomes 1 and :2 (Fignres 9. 14 anil 15). and fire sporocytes had heterozygous tramslocations that were not clefinitely identified, but were probably between chromosomes $t$ amd is and chromosomes $t$ and 10 .

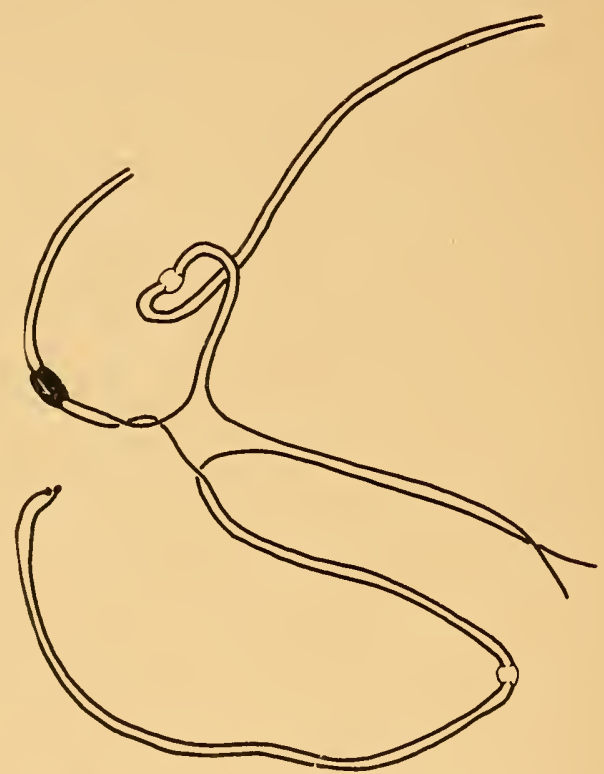

Figure 9. Heterozigous translocation between chromosomes i and 2 found in a few sporecytes of an anther. A photograph wi the sporocyte from which the drawing was made is slown in figure 14 . The translocation occurred near the kimob on the long arm of chromosome 2 and about mid-way on the lome arm of chromosome 1. Plant 38-382-1. (Perligrece 2.37() $21+\lambda)$.

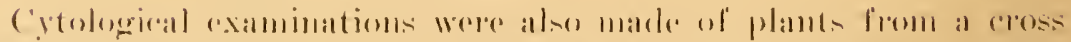

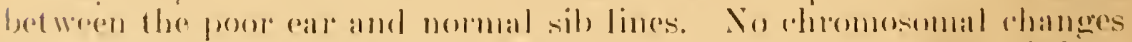

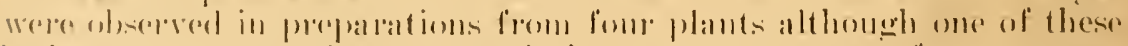

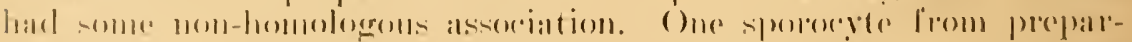

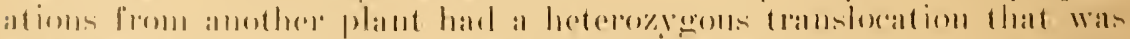
not (o)

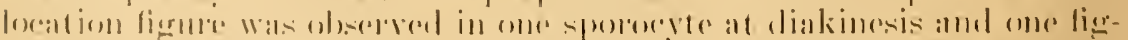

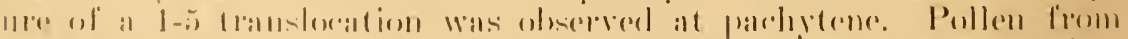

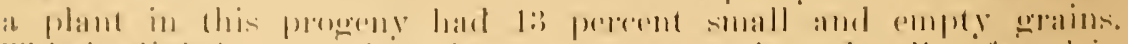

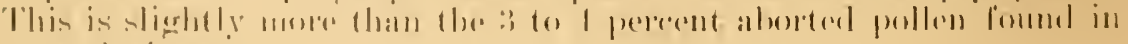
normal plantis: 
Since a cytological examination is made of relatively fom spore ocytes, and part of the tasiel is left to devolope matme pollen, it is diflicult to estimate the fiecpuency of ocemrence of any ahromosomal changes taking place in sporocytes or pre-meiotic cells from an analysis of the chromosomes. Howerer. if any changes are prosent in the pollen, they should be detected in the next generation. I comnt was made for any transmission of semi-sterility after using a plant from a 'ross with the poor-ear line as the pollen parent. From plants of this cross 50 normal ears were obtained and one semi-sterile. Inother cross had 30 normal ear's, one semi-sterile and one with a portion of the ear appearing semi-sterile. These have not as yet been examined cytologically to determine if any chromosomal change had been transmitted. These numbers are still too small to enable a determination of the frequency of occurrence of any chromosomal changes to be made.

\section{DISCUSSION}

In the foregoing accomnt of sterility in inbred and hybrid maize the emphasis has been placed on the kind of change observed rather than on the frequency of occurence. Any precise determination of the frequency of mutational or chromosomal changes must be made in experiments designed for such a purpose.

In each of the groups of semi-sterile ear's used, 50 percent of the ears had no transmission of the sterility or doubtful transmission to succeeding generations (Table 1). This is in agreement with the observation that many poorly filled ears of corn are manifestations of environmental conditions and are not due to any inherent chromosomal changes which affect the fertility of the gametes. That chromosomal alterations do occur was shown by finding translocations and inversions in the succeeding generations from half the progenies growll.

The translocations reported here have arisen withont any treatment and are thus considered of naturally occurring origin. They are different from any previonsly reported translocations. Burnham $(5,6)$ found a sterility in maize in inbred material, and Lindstrom (21) has emphasized that mutations may be readily isolated from inbred lines of maize. A comprehensive analysis of defective types of endosperm development originating in rarieties, inbreds and hybrids has been presented by Mangelsdorf (22).

The frequency of spontaneous chromosomal changes (translocations and inversions) is not known for maize, but Stadler (38) found 0.9 percent of the control plants in an experiment with $\mathbf{X}$-rays and ultra-violet radiation to have segregation for defective pollen. In totalling the ears harvested in the field corn test reported in this discussion, there was found a maximum of 0.11 percent plants with semisterile ears, those segregating defective ovules. Since many different lines were totalled in determining this value, it cannot be considered one clerived from a "control". 
If there is no deficiency as-ociated with a translocition. or no selection aganst ganetes carrving it. lines homozygous for a change are automatically established durmo inbreeding in the same manner that a wene for a plant character is obtained homozyous in an inbred line. 'The inbred 696 -3.3e was found to be homozyous for a translocation between chromosomes 1 and 2. Another. a sweet corn inbred. Was previously found at the Connecticut Experiment Station to produce all semi-sterile ears when crossed with other inbreds. Thi= was also homozygous for a translocation (identified by Burnham). Inbreds homozyous for translocations are not detected, until crosses are made with them unless there is some effect on the growth of the plants. They are useless in the production of hybrids since all the resulting crossed progeny is semi-sterile.

The type of sterility which is transmitted either through the pollen or through the egroells is also occasionally found in inbred and hybrid stocks. Thhen the pollen is serregating defective types but the cars are normal, the condition camnot be recognized by field examination. An inbred carrving a factor for pollen abortion would be at no serions disadrantage if it were normal in other respects and produced adequate amounts of pollen in spite of the sterility. When a factor. for orule abortion is present and the pollen is normal, the condition would be easily recognized by the semi-sterile cars produced, and the line would be discarcled for commercial prodnction.

J)generative changes which occur sporadically in inbred material are of interest in theoretical problems but are a hindrance in a practical breeding program. Many of these may have physiological or ellrironmental bases for expression. They aie dillicult to analyse genatically and there is a possibility that the presence of modifying factors nay aflect the phenotype, particularly in instances in which the ratios difler significantly from theoretical Mendelian ratios. When sib lines difler after a number of years of inbreeding, as was fomd to be the case in line $\mathrm{C} 237$, the inferences may be drawn that the inbreds may be rery susceptible to critical envirommental conditions. that homo\%ycosity las not been attained or that the frequency of damues afferting the phenotype of the plant is relatively hioh. In the lins

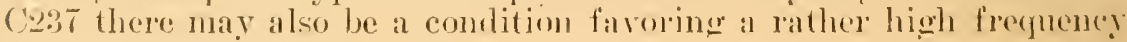
of rhromosomal changes.

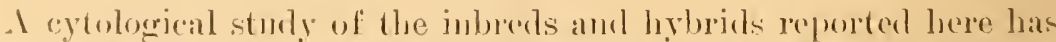
show that many of the changes had weconed withont producing any visible cflect on the plant growth althomerh the fertility of the gam-

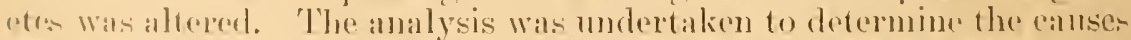

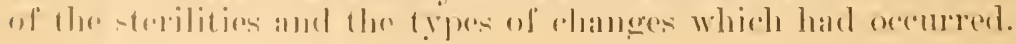

\section{SUMMARY}

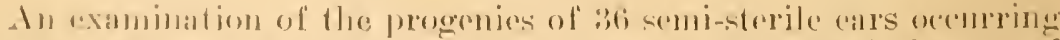
spontameomaly among hyludils grown in ter plots showed that 18 of

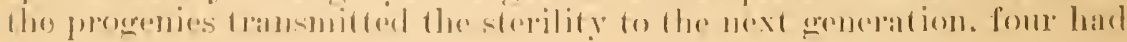


doubtful transmission of the sterility and 14 had no transmission of the sterility.

Six translocations, an inversion and three factors for lethal gametes were found among the progenies in which the sterility was transmitted to succeeding generations.

Five inbred lines of dent corn were analyzed cytolowically to determine the causes of sterility in the inbreds and in hybrids with them. 'Two wer'c characterized by variable amounts of asynapsis. One was found to have a small inversion and one was found to be homozygous for a translocation. The fifth inbred was studied in relation to a degenerative type of ear development and was found to have anther's with the majority of the sporocytes with normal chromosomes. A few sporocytes were found having heterozygous translocations.

\section{LITERATURE CITED}

1. Beadle, G. W. Genetical and cytological studies of Mendelian asynapsis in Zea mays. N. Y. (Corne11) Agr. Expt. Sta. Mem. 129. 1930.

2. Further studies in asynaptic maize. Cytologia $4: 269-287.1933$.

3. Bergner, A. D., J. L. Cartledge, and A. F. Blakeslee. Chromosome behavior due to a gene which prevents metaphase pairing in Datura. Cytologia $6: 19-37.1934$.

4. Burnham, C. R. An interchange in maize giving low sterility and chain configurations. Nat1. Acad. Sci. Proc. 18:434-440. 1932.

5. Abnormal genetic ratios in chromosome 1 of maize associated with pollen abortion. Amer. Nat. $69: 60$ (Abstract). 1935.

6. Cytogenetic studies of a case of pollen abortion in maize. Genetics $26: 460-468,1941$.

7. and J. L. CARTLEDGE. Linkage relations between smut resistance and semi-sterility in maize. Amer. Soc. Agron. Jour. $31: 924-933.1939$.

8. Darlington, C. D. Recent advances in cytology. Second edition. P. Blakiston's Son and Co. Philadelphia. 1937.

9. Dobzhansky, Th. and M. M. Rhoades. A possible method for locating favorable genes in maize. Amer. Soc. Agron. Jour. 30:668-675. 1938.

10. EAst, E. M. Heterosis. Genetics $21: 375-397.1936$.

11. Goodspeed, T. H. Chromosome unbalance and the asynaptic condition as induced in Nicotiana by X-radiation. Sixth Int. Cong. Genetics Proc. 2:67-69. 1932.

12. HirschHorN, £. Observaciones sobre la meiosis normal y un caso de asinapsis en Sisyrinchium. Rev. Argentina de Agron. 1:66-75. 1934.

13. Jenkins, M. T. The effect of inbreeding and of selection within inbred lines of maize upon the hybrids made after successive generations of selfing. Iowa State Col. Jour. Sci. 9:215-236. 1935.

14. JoNEs, D. F. The effects of inbreeding and crossbreeding upon development. Conn. Agr. Expt. Sta. Bul. 207. 1918.

15. The attainment of homozygosity in inbred strains of maize. Genetics $9: 405-418.1924$.

16. Continued inbreeding in maize. Genetics 24:462-473. 1939.

17. Chromosome degeneration in relation to growth and hybrid vigor. Natl. Acad. Sci. Proc. 28:38-44. 1942.

18. and P. C. MANGELSDORF. The improvement of naturally crosspollinated plants by selection in self-fertilized lines. I. The production of inbred strains of corn. Conn. Agr. Expt. Sta. Bul. 266. 1925.

19. Koller, P. C. Asynapsis in Pisum satizum. Jour. Genet. $36: 275-306.1938$.

20. Levan, A. The cytology of Allinm amplectens and the occurrence in nature of its asynapsis. Hereditas $26: 353-394.1940$. 
21. Lixdstrom, E. II. Some new mutants in maize. Iowa State Col. Jour. Sc1 $9: 237-246.1935$.

22. MaxgelsDorf. P. C. The genetics and morphology of some endosperm characters in maize. Conn. Agr. Expt. Sta. Bul. 279. 1920.

23. Nechanical separation of gametes in maize. Jour. Hererl. $23: 289-295 . \quad 1932$.

24. MicClistock, B. A cytological clemonstration of the location of an interchange between two non-homologous chromosomes in Zea mays. Natl. Acad. Sci. Proc. $16: 791-796.1930$.

25. Cytological observations of deficiencies involving know genes, translocations and an inversion in Zca mays. Mo. Agr. Expt. Sta. Res. Bul. 163. 1931.

26. The fusion of broken ends of sister half-chromatids following chromatid breakage at meiotic anapliases. Mo. Agr. Expt. Sta. Res. Bul. 290. 1938.

27. The production of homozygous deficient tissues with mutant characteristics by means of the aberrant mitotic behavio: of ring-shaped chromosomes. Genetics $23: 315-376.1938$.

28. MYers, II. M. and L. Powers. Meiotic instability as an inherited character in varieties of Triticnm acstizmm. Jour. Agr. Res. $56:+41-452.1938$.

29. Powers, L. and A. O. DAHL. Failure of diakinesis and metaphase pairing and the behavior during meiosis of univalent cliromosomes in Zca mays. Jour. Agr. Res. $54: 655-668,1937$.

30. Rhondes, M. M. and V. H. Rhondes. Genetic studies with factors in the tenth chromosome in maize. Genetics 21:302-31t. 1939.

31. Richardsox, M. M. Mciosis in Crepis. II. Failure of pairing in Crepis capellaris. (L.) Wallr. Jour. Genet. $31: 110-143.1935$.

32. Roberts, L. M. The effects of translocation on growth in Zea mays. Genctic: $27: 58+-603.19+2$.

33. Singleton, IV. R. Complete elimination of certain classes of gametes in Zcu. Sixth Int. Cong. Genet. Proc. 2:182-18t. 1932

34. Influence of fomale stock on the functioning of small pollen male gametes. Nat1. Acad. Sci. Proc. 26:102-104. 1940

35. Hybrid vigor and its utilization in sweet corn breeding. Amer. Nat. $75: 48-60.19+1$.

36. and P. C. MAxcissonf. Gametic lethals on the fourt chromosome of maize. Genetics $25: 366-390.1940$.

37. SpRAGCE, G. 1: Hybrid vigor and growth rates in a maize cross and its re ciprocal. Jour. Agr. Res. $53: \$ 19-830.1936$.

38. Stanler, L. J. The comparison of ultraviolet and X-ray effects on mutation. Cold Spring Harbor Sim. on Quant. Biol. 9:168-177. 1941.

39. STrktevis, A. H. and G. W. Beande. An introduction to genetics. IV. B Saunders Co., Philadelphia. 1940.

40. Thompsos, IV. P. and I. IUtcheson. Chromosome belavior and fertility in diploid wheat with transiocation complexes of four and six elromosomes. Canarl. Jour. Res. $20: 267-281.19+2$. 
University of
Libraries 


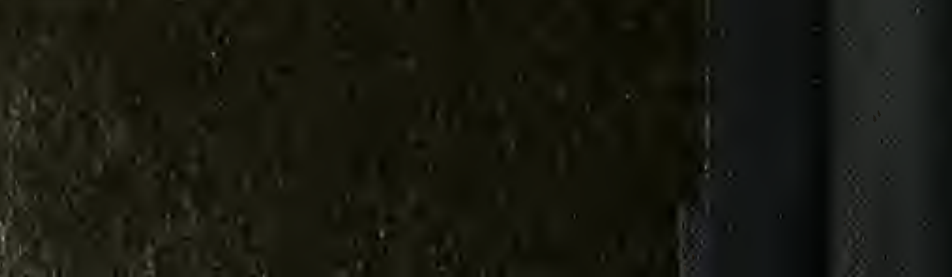

